\title{
THE EFFECT OF TOXIC FACTORS ON INTRACELLULAR PROTEINASE ACTIVITY IN FRESHWATER FISH
}

\author{
E. I. KAIVARAINEN, N. N. NEMOVA, M.Y. KRUPNOVA, L. A. BONDAREVA \\ Institute of Biology, Karelian Research Centre. RAS, \\ Petrozavodsk, Russia
}

Received July 27, 1998

Accepted September 21, 1998

\begin{abstract}
Kaivarainen, E. I., N. N. Nemova, M. Y. Krupnova, L. A. Bondareva: The Effect of Toxic Factors on Intracellular Proteinase Activity in Freshwater Fish. Acta vet. Brno 67, 1998: 306-316.

The effect of ore-dressing sewage on intracellular proteinase activity was studied in the larvae of European whitefish and rainbow trout and in some types of freshwater fish (pike, roach, and perch) tissue (gills, liver, kidney, spleen, and muscles) in aquarium experiments and in contaminated and clean water bodies. Cathepsin D (lysosome proteinase) activity was observed to increase 1.5-2.0 times in the larvae of rainbow trout present in undiluted sewage and at 5 -fold dilution in the aquarium experiment, as compared with the control. This effect increased 7 times in the larvae of European whitefish at 5-fold dilution, as compared with the control. Similar changes were reported for the tissues of pike and roach caught in a contaminated zone. Cathepsin D activity increased 3 and 6 times in the gills and liver of pike, as compared with the control. Cathepsin B (lysosome proteinase) activity decreased about 1.5 times in the larvae of rainbow trout kept in aquaria with undiluted ore-dressing sewage and subjected 5 -fold dilution. In addition, $\mathrm{Ca}^{2+}$-activated proteinases (neutral cytosol proteinases) were found to be less active in the muscles of pike and roach studied affected by ore-dressing sewage in a contaminated zone, so that calpain I activity declined 1.5-2.0 times, and calpain II activity decreases two times or was not detected at all. Similar effects were reported for the perch muscle caught in the aquarium experiment with undiluted sewage. The above results show that some parameters of intracellular proteolysis can be used as a biochemical test in biomonitoring of water bodies.
\end{abstract}

Cathepsins, calpains, ore-dressing sewage, biotesting

The impact of human activities on water bodies has substantially increased in the past few years.Therefore, more attention is now given to the existence and survival of aquatic organisms in contaminated water (Alabaster and Lloyd 1984; Evtushenko et al. 1985; Luky ane nko 1983). Fish are extremely sensitive to toxins that can inhibit metabolic pathways and reduce the resistance of cells in their organism (Evtushenko et al. 1985; $\mathrm{B}$ ard ach and Life 1982). It should be noted in this connection that most types of industrial sewage contain at least two toxicants. It is difficult, therefore, to assess their toxic effect on fish and other organisms.

The effect of toxicants on the organism is accompanied by the involvement of the cellular and molecular mechanisms that control metabolic homeostasis. The degree of toxicity is related to the efficiency of protective and restoring mechanisms in the tissue analysed, such as a system of intracellular proteolysis with lysosomal and nonlysosomal pathways. Proteinases can inactivate, transform, and excrete chemical compounds. Proteinase activity is an important parameter of biotesting because biochemical changes in the cells and tissues 
of an organism are commonly observed before external indications of intoxication are apparent (Stroganov et al. 1983; Sidorov et al. 1993).

Cathepsins B, H, I, and D are the main proteinases of lysosomes, and a major contribution to nonlysosomal proteolysis is made by neutral $\mathrm{Ca}^{2+}$-activated cytosol proteinases (calpains).

The biological role of various proteinases in cellular functions was assessed. The processing, rather than digestive, activity of these enzymes makes it possible to directly modulate the activities and/or functions of other proteins both precisely and irreversibly. One example of such modulating intracellular proteinase is calpain. Micro- and $\mathrm{m}$-calpains, also known as calpains I and II, respectively, are controlled by $\mathrm{Ca}^{2+}$ concentration. Calpain is believed to be involved in various $\mathrm{Ca}^{2+}$-mediated intracellular signalling pathways. However, all attempts to throw more light on the functions of calpain in vivo have failed.

It was interesting, therefore, to assess the effect of sewage discharged by ore-dressing plants on the activity of calcium-activated proteinases (calpains) in the skeletal muscles and that of cathepsin D and B in the various tissues of some freshwater fish species.

\section{Materials and Methods}

Pike (Esox lucius), roach (Rutilus rutilus) and perch (Perca fluviatilis) were studied along with the larvae of rainbow trout (Salmo gairdneri R.) and whitefish (Coregonus lavaretus). Fish caught in a "clean" zone (uncontaminated lake) were compared with those collected in a "polluted" area where infiltration water from an ore-dressing plant was stored. Perch and the larvae of rainbow trout and whitefish were exposed to the same type of concentrated sewage and at 5-, 25-, 125-, and 600-fold dilution for 15 days. The fish analysed were kept in aquaria in summer time under conditions identical to their natural environment. Altogether, 10 samples of freshwater fish were analysed in each experiment $(n=10)$.

The ore-dressing sewage contains a complex mixture of metals with high potassium concentration and a high percentage of suspended ore particles (Morozov 1998). In the contaminated zone. high water mineralization is primarily due to the presence of $\mathrm{K}+$ and sulphate ions (Table). The percentages of nitrates, organic nitrogen, and lithium are observed to increase. High alkaline and alkaline-earth metal and hydrocarbonate concentrations in the polluted zone were responsible for the shift of $\mathrm{pH}$ toward the alkaline region (8.2-8.4). Such conditions provide a geochemical barrier for the migration of most heavy metals. Therefore, the concentrations of elements that accompany iron ( $\mathrm{Co}, \mathrm{Ni}, \mathrm{Cr}$ ) are a few microgrammes per litre of water, which slightly exceeds the indices of these elements observed in the clean zone.

Table 1

Chemical composition of water in clean and polluted zones $(\mathrm{mg} / \mathrm{l})$

\begin{tabular}{|l|c|c|c|c|c|}
\hline & $\mathrm{Ca}^{2+}$ & $\mathrm{Mg}^{2+}$ & $\mathrm{Na}^{+}$ & $\mathrm{K}^{+}$ & $\mathrm{SO}_{4}$ \\
\hline clean \\
polluted & 1.6 & 0.6 & 1.2 & 4.4 & 2.2 \\
\hline
\end{tabular}

To estimate $\mathrm{Ca}^{2+}$ - activated proteinase (calpain I and II) activity, fish muscles $(5 \mathrm{~g})$ were homogenized in buffer A with $0.25 \mathrm{M}$ sucrose (1:3) and centrifuged (105 000 $\mathrm{g} \times 60 \mathrm{~min}$ ). Gel chromatography of samples was done on columns with Ultragel AcA34 to separate calpastatin, a cytosol protein inhibitor of calpains, at elution rate of 22 $\mathrm{ml} / \mathrm{h}$ with buffer $\mathrm{A}$ ( $10 \mathrm{mM}$ tris- $\mathrm{HCl} \mathrm{pH} 7.5$, containing $50 \mathrm{mM} \mathrm{NaCl}, 4 \mathrm{mM}$ EDTA, $5 \mathrm{mM}$ mercaptoethanol). $\mathrm{Ca}^{2+}$. activated proteinase activity in 3.5-4.0 eluent fractions was estimated from hydrolysis of caseine by a conventional method (Murachi et al. 1981). Reaction mixture for both calpains contained $0.4 \%$ casein, $5 \mathrm{mM}$ cysteine or dithyotreitol, $50 \mathrm{mM}$ imidazole- $\mathrm{HCl}$ buffer at $\mathrm{pH} \mathrm{7.5,} \mathrm{and} \mathrm{enzymatic} \mathrm{solution.} \mathrm{Its} \mathrm{total} \mathrm{volume} \mathrm{was} 1 \mathrm{ml}$ and 10 $\mathrm{mM} \mathrm{Ca}{ }^{2+}\left(\mathrm{CaCl}_{2}\right)$. After $30 \mathrm{~min}$ incubation at $30^{\circ} \mathrm{C}$ the reaction was terminated by adding $1 \mathrm{ml} 10 \%$ trichloracetic acid. The concentration of acid-soluble products was determined spectrophotometrically at $280 \mathrm{~nm}$. The reaction mixture used as control had the same composition, but $\mathrm{Ca}^{2+}$ was added upon termination of the reaction. Enzymatic activity was estimated in units of activity in $1 \mathrm{ml}$ eluent from the Ultragel column (absorbance units at $280 \mathrm{~nm}$ per $\mathrm{ml}$ eluent). One unit of calpain activity was defined as the amount that caused an increase in the absorbance at 280 $\mathrm{nm}$ of 1.0 for $30 \mathrm{~min}$ according to Murachi et al. (1981).

Cathepsin D activity was assessed by the slightly modified Anson method (Alexeenko 1968) based on the ability of the enzyme to hydrolyse haemoglobin (1.0\% solution of bovine haemoglobin in $0.1 \mathrm{M}$ acetate buffer, pH 3.6). Cathepsin B activity was estimated by decomposition of $0.065 \mathrm{M}$ benzoylarginine ethyl ether solution (BAEE) 
in $0.1 \mathrm{M}$ acetate buffer at $\mathrm{pH} .0(37 \mathrm{C} \times 30 \mathrm{~min})$. Reaction products were detected spectrophotometrically at 280 and $525 \mathrm{~nm}$. respectively (Alexeenko 1968). Enzyme activity is presented in the conventional units used in the literature on proteinases. Because we deal with non-pure enzymes, activity of cathepsin D and B be can measured in absorbance units at $280 \mathrm{~nm}$ and $525 \mathrm{~nm}$ per g tissue/hour, respectively.

The results obtained were statistically processed, using Wilkocxon-Mann-Whitney nonparameter variation criterion (Gubler and Genkin 1969).

\section{Results and Discussion}

The effect of ore-dressing sewage containing various concentrations of metals on the enzymes of intracellular proteolysis in fish was studied in aquaria. Cathepsin D activity was shown to increase in the early larvae of European whitefish and rainbow trout with a rise in the concentration of contaminants relative to control (Figs. 1 and 2). This increase was more

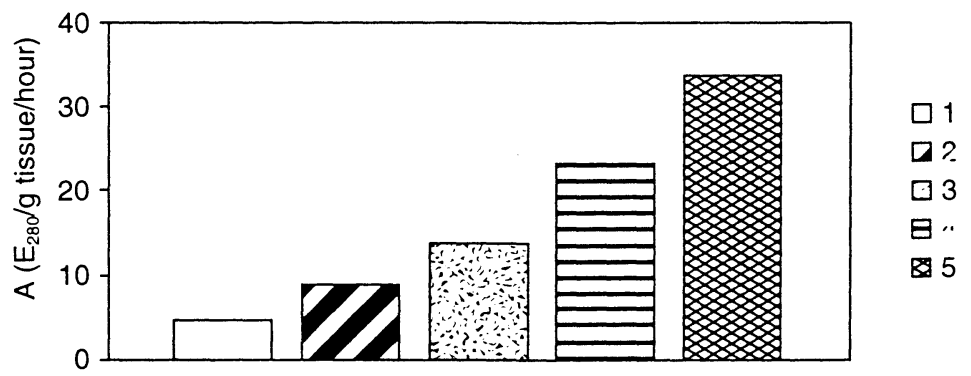

Fig. 1.

The effect of ore-dressing sewage on larval cathepsin $D$ activity in European whitefish. Sewage dilution: 1 - control, $2-\times 600,3-\times 125,4-\times 25,5-\times 5$.

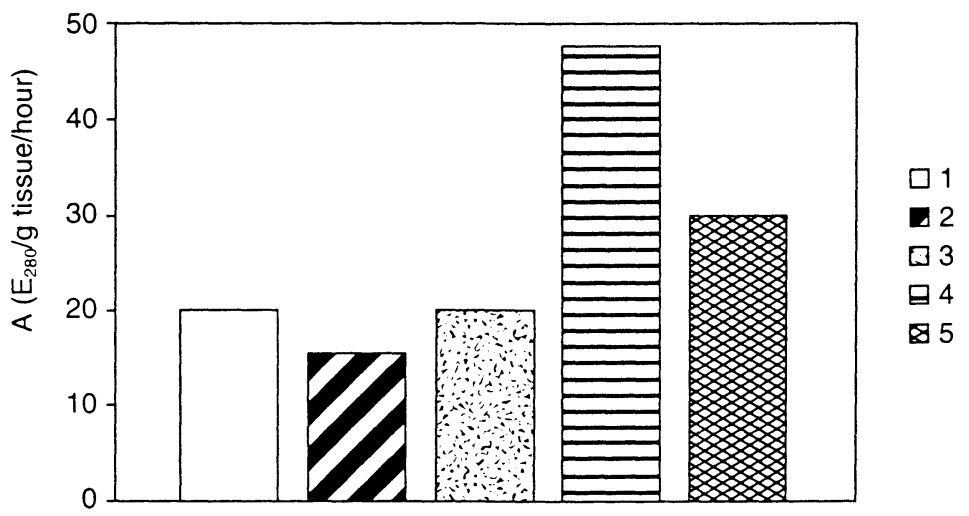

Fig. 2.

The effect of ore-dressing sewage on larval cathepsin $\mathrm{D}$ activity in rainbow trout. Sewage dilution: 1- control, $2-\times 125,3-\times 25,4-\times 5,5$ - concentrated sewage.

distinct and pronounced in European whitefish larvae. In rainbow trout larvae, changes in cathepsin D activity were observed at 5-fold dilution of water from an infiltration water reservoir, whereas in whitefish larvae this enzyme became more active after 125 fold dilution of initial contaminated water. 
Cathepsin B activity measured in the larvae of the fish studied was slightly lower in the experimental group than in control (Fig. 3).

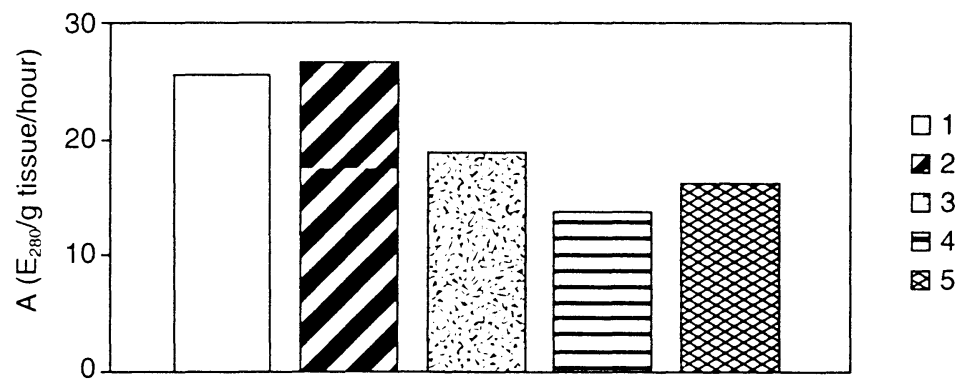

Fig. 3.

The effect of ore-dressing sewage on larval cathepsin $B$ activity in rainbow trout. Sewage dilution: 1 - control, $2-\times 125,3-\times 25,4-\times 5,5$ - concentrated sewage.

The activation of cathepsin $\mathrm{D}$ was fairly distinct in all the tissues, particularly in the liver and gills, of pike kept in the ore-dressing sewage zone (Fig. 4). This proteinase was also

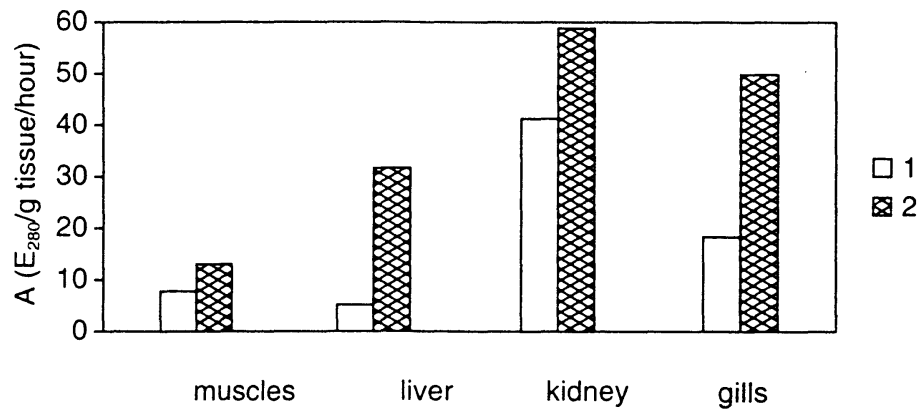

Fig. 4.

The effect of ore-dressing sewage on cathepsin D activity in pike tissues. 1 - clean zone, 2 - polluted zone, A - enzyme activity.

shown to increase in the muscle and spleen tissues of roach (Fig. 5). Cathepsin B activity remained unchanged in the same tissues of fish caught in contaminated water, but declined in pike gills. The ions of mercury and other heavy metals, ammonium, and chemical agents that affect the percentage of SH groups in animal tissues are known to inhibit cathepsin B activity because this enzyme is cysteine (thiolic) proteinase (Nemova 1991).

The increase of cathepsin D activity in the larvae and tissues of fish that form an experimental group is compensatory. As a result, the defective (damaged) cell structures, formed under the influence of toxicants present in contaminated water, are hydrolysed and removed. This process is occasionally accompanied by more active phagocytosis and excretion in cells. A similar effect was shown earlier when studying the impact of various zinc and ammonium ion concentrations, sewage discharged by pulp-and-paper plants and some other substances on cathepsin D activity in the tissue, eggs, and larvae of some fish species (Nemova and Sidorov 1990). 


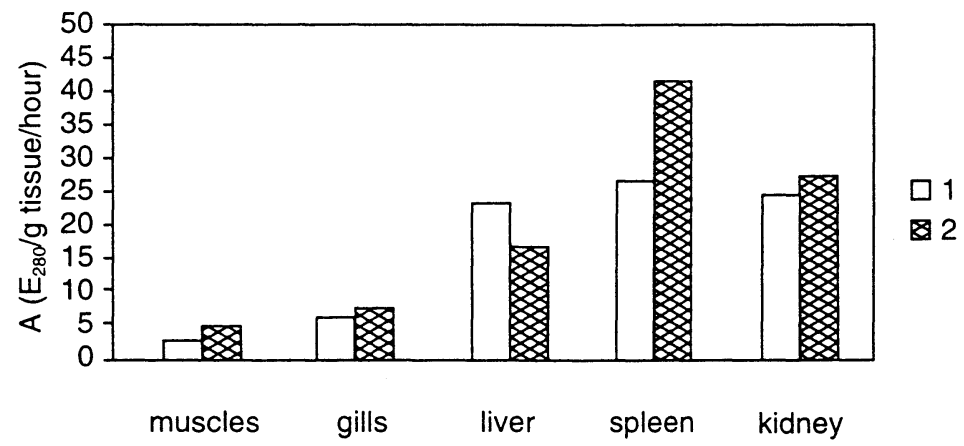

Fig. 5.

The effect of ore-dressing sewage on cathepsin D activity in roach tissues. 1 - clean zone, 2 - polluted zone, A - enzyme activity.

The results of our study on calpain activity are shown in Fig. 6, 7, and 8. After the cytosolic fractions of fish muscles are chromatographically separated on Ultragel AcA34 calpain activity is detected in two fractions (Fig. 6), as shown earlier for some sturgeon, salmon, and carp species (Nemova et al. 1993, 1994; To y ohara et al. 1989). It is known from the literature (Murachi 1983; Murachi et al. 1981; Toy o hara et al. 1989) that calpain II, which has bigger molecular mass than calpain I, is the first to be eluted from the Ultragel AcA34 column.

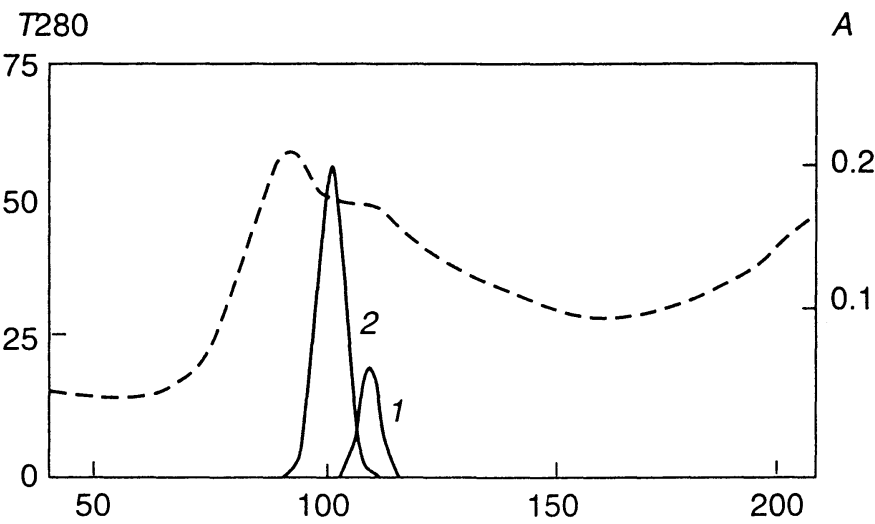

Fig. 6.

Calcium-activated roach muscle proteinases determined by UltragelAcA34 $(5 \times 95)$ chromatography T280 - protein uptake. A - activity (unit/ml), 1 - calpain I, 2 - calpain II.

In the muscles of all the fish caught in the contaminated zone and in the aquarium experiment a mixture of toxicants was clearly observed to inhibit $\mathrm{Ca}^{2+}$-activated proteinase activity. This primarily applies to calpain II which is activated by millimolar $\mathrm{Ca}^{2+}$ concentrations (Murachi 1983) (Figs 7 and 8).

Some evidence available in the literature shows that calpain II is usually activated in animal tissues under pathological conditions (Kawashima et al. 1986). This is presumably related to the adaptive reactions of cells. The same effect was observed in the tissue of the Russian sturgeon Acipenser gueldenstaedti caught in the Volga river delta. This species displayed so-called "muscle stratification" caused by industrial sewage (Nemova et al. 1993). 

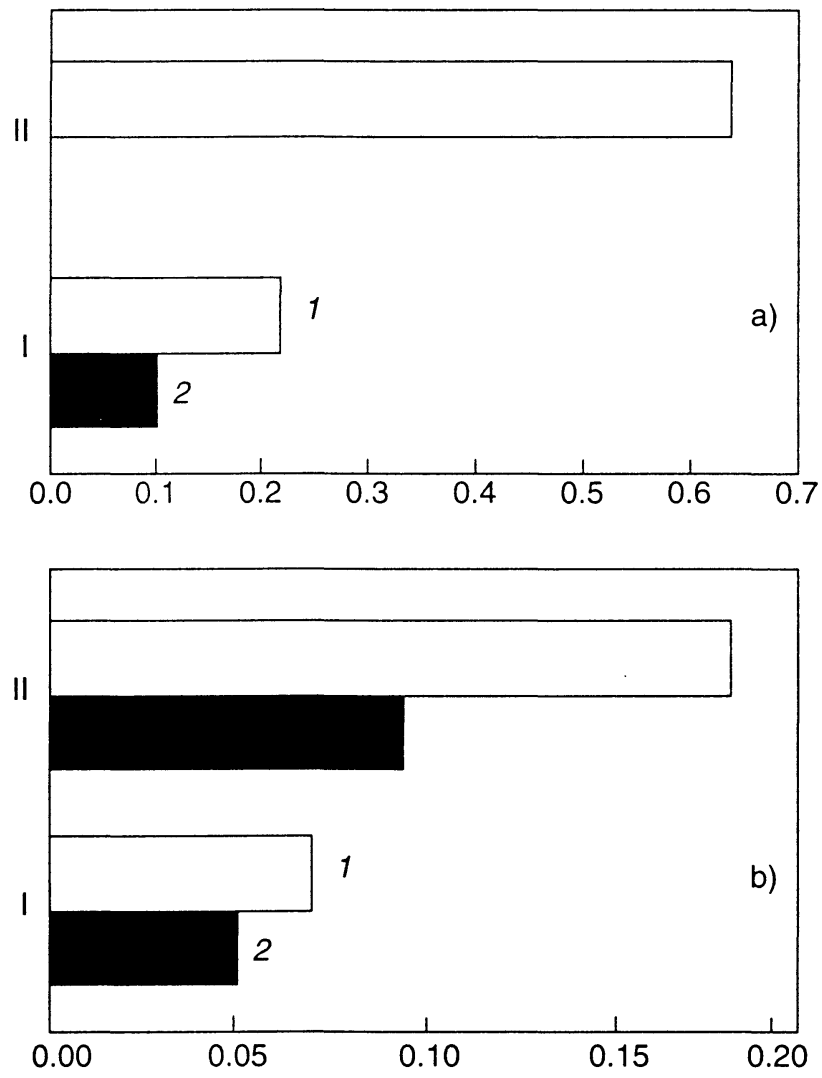

Fig. 7.

Effect of ore-dressing seware on calpain I (I) and calpain II (II) activites in pike (a) and roach (b) muscles from clean (1) and polluted (2) zones.

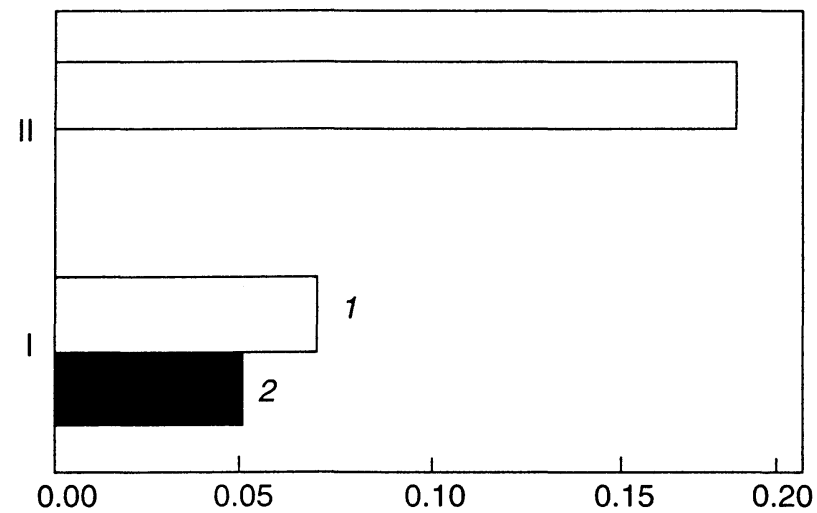

Fig. 8 .

Calpain I (1) and calpain II (2) activity in perch muscles (aquarium experiment), 1 - control, 2 - experiment (water from a polluted zone) 
In the case discussed, this form of calpain becomes less active in the muscles of fish living in polluted zone. The inhibiting effect of toxicants was also reported for calpain I which is activated by micromolar $\mathrm{Ca}^{2+}$ concentrations, and is more important for the cell physiologically (Murachi 1983).

The effect of toxicants on $\mathrm{Ca}^{2+}$-activated proteinases is controlled by a complex mechanism. Toxic agents can directly influence the $\mathrm{S}-\mathrm{H}$ groups of enzymes, because these enzymes are thiolic proteinases, and their inhibitor-activator ratio. They can change the concentration of intracellular $\mathrm{Ca}^{2+}$ required for the activation of these proteinases. Changes in cooperative interaction on the surface of an enzymatic protein globule caused by ionic effects cannot be ruled out either. When the proteolytic activity of lysosomes and cytosol is inhibited, the adaptive potential of the cell is expected to diminish and the vital processes and physiological functions of the organism are likely to be disturbed.

The results obtained have led the authors to conclude that the distinct increase of cathepsin $D$ activity in freshwater fish tissues and the decrease of calpain activity in the muscles, caused by the effect of a complex mixture of toxicants present in sewage discharged by ore-dressing plants in aquaria and in natural water bodies, suggest that this biochemical test can be used in monitoring of water bodies contaminated by industrial sewage. It should be emphasized that if intracellular proteolysis in fish tissues is studied biochemically by the method described, then a toxic effect is revealed at an early stage, when macroscopic changes are not apparent yet.

\section{Vliv toxických faktorů na vnitrobuněčnou proteinázovou aktivitu u sladkovodních ryb}

Vliv odpadních vod $\mathrm{z}$ úpravny rudy na vnitrobuněčnou proteinázovou aktivitu byl sledován na larvách Coregonus lavaretus a pstruha duhového a na rủzných tkáních (žábry, játra, ledviny, slezina a svalovina) sladkovodních ryb (štika, plotice a okoun) $\mathrm{v}$ laboratorních podmínkách $\mathrm{v}$ kontaminované a čisté vodě. U aktivita katepsinu D (lysosomální proteináza) bylo pozorováno 1,5-2násobné zvýšení u larev pstruha duhového držených $v$ neředěné odpadní vodě a při 5násobném zředění př́i experimentu v akváriích ve srovnání s kontrolními rybami. U larev Coregonus lavarentus volně došlo k 7 násobnému zvýšení ve vodě $5 \times$ zředěné ve srovnání $s$ kontrolou. Podobné změny byly pozorovány ve tkáních štiky a plotice odlovených z kontaminované oblasti. Aktivita katepsinu D se zvýšila 3 a 6 krát v žábrách a játrech štiky ve srovnání s kontrolou. Aktivita katepsinu B se snížila 1,5krát u larev pstruha duhového držených $v$ akváriích $s$ neředěnou odpadní vodou $z$ úpravny rudy i v 5 krát zředěné. Kromě toho, proteinázy aktivované $\mathrm{Ca}^{2+}$ (neutrální cytosolové proteinázy) měly nižši aktivitu ve svalovině štiky a plotice z kontaminované zóny, zatímco aktivita calpainu I poklesla 1,5-2krát a calpainu II dvakrát nebo nebyla detekována u všech. Podobné působení bylo pozorováno ve svalovině okouna při akvarijním experimentu v neředěné odpadní vodě. Uvedené výsledky ukazují, že některé parametry vnitrobuněčné proteolýzy mohou být využity jako biochemický test při monitoringu vod.

\section{Acknowledgements}

The present study was supported by the Russian Fundamental Research Foundation. Project 98-04-48482.

\section{References}

ALABASTER. D.. LLOYD, R. 1984: Water quality criteria in freshwater fish. Moscow; 343 p.

ALEXEENKO. L. P. 1968: Methods for estimation of proteolytic enzyme activity. In: Sovremennye metody biokhimii. Medicina. Moscow. pp. 115-130 
BARDACH. I. E., LIFE, I. 1982: Pollution effects on fish. In: Encycl. Environ. Sci. and Eng. F.-P. No. I, pp. 871 877

EVTUSHENKO, Z. S., BELCHEVA, N. N., LUKYANOVA, O. N. 1985: Biochemical mechanisms of the response of marine organisms to heavy metals. In: Experimentalnaya vodnaya toxicologia. Abstract. Riga, pp. 20-28

GUBLER, E. V., GENKIN, A. A. 1969: The use of nonparametric statistical criteria for estimation of differences between two experimental groups in medical and biological studies. Medicina, Moscow, $25 \mathrm{p}$.

LUKYANENKO, V. I. 1983: General toxicology. Moscow, 320 p.

KAWASHIMA, S., INOMATA, M., IMAHORI, K. 1986: Autolytic and proteolytic process of calcium-activated neutral protease and independent of each other. Biochem. Res. 7: 327-331

MOROZOV, A. K. 1998: Chemical composition of water.In: Sovrem. sost. vodn. obyek. Resp. Karelia. Petrozavodsk. KRC, RAS (in press)

MURACHI, T., HATANAKA, M., IASUMOTO, I., TANAKA, K. 1981: A quantitative distribution study on calpain and calpastatin in rat tissues and cells. Biochem. Int. 2: 651-656

MURACHI, T. 1983: Intracellular $\mathrm{Ca}^{2+}$ protease and its inhibitor protein: calpain and calpastatin. In: Calcium and cell function. Academic Press. London 4: 377-409

NEMOVA, N. N. 1991: The properties and physiological implication of intracellular proteinases in fish tissues. In: Uspekhi sovr. biol. 111: 948-954

NEMOVA, N. N., KAIVARAINEN, E. I.., MOSOLOV, V. V. 1993: $\mathrm{Ca}^{2+}$-dependent fish tissue proteinases. In: Biokhimicheskie metody v ecologicheskikh i toxicologicheskikh issledovaniyakh. Petrozavodsk, pp. 82-88

NEMOVA, N. N., KRUPNOVA, M. Y., KAIVARAINEN, E. I., VOLKOV, I. V. 1994: The effect of toxic factors on proteolytic activity in the eggs and early larvae of fish. In: Izvestia RAN, Ser. biol.: 605-610

NEMOVA, N. N., SIDOROV, V. S. 1990: The effect of some toxicological factors on lysosomal proteinases in freshwater fish. Hydrobiol. Journ. 26: 69-73

NEMOVA, N. N., SIDOROV, V. S., GRIGORYEVA, L. I., VALUEVA, T. A., MOSOLOV, V. V., KAIVARAINEN, E. I., LUKYANENKO. V. I. 1992: Intracellular proteinases in the organs of the sturgeon Acipenser guldenstaedti showing muscle stratification. In: Voprosy ikhtiologii, 32: 57-62

SIDOROV, V. S., VYSOTSKAYA. R. U., NEMOVA, N. N., et al. 1993: Evolutionary aspects of ecological and biochemical monitoring. In: Biokhimicheskie metody v ecologicheskikh i toxicologicheskikh issledovaniyakh. Petrozavodsk, pp. 5-35

STROGANOV, O. F., FILENKO, G. D., LEBEDEVA, L. I., et al. 1983: Principles of basic biotesting of sewage water and estimation of the quality of natural reservoirs. In: Teoreticheskie voprosy biotestirovania. Moscow, pp. 21-30

TOYOHARA, H., MAKINODAN. I. 1989: Comparison of calpain I and calpain II from carp muscle, Comp. Biochem. Physiol. 9213: 577-581 